\title{
KORELASI PANJANG RADIUS DENGAN TINGGI BADAN PADA MAHASISWA FAKULTAS KEDOKTERAN UNSRAT ANGKATAN 2010
}

\author{
Raja M. Simatupang \\ Shane H. R. Ticoalu \\ Djon Wongkar
}

\begin{abstract}
Bagian Anatomi Histologi Fakultas Kedokteran Universitas Sam Ratulangi Manado
Email: simatupang_raja@rocketmail.com
\end{abstract}

\begin{abstract}
There has been an increase in cases of post-mortem mutilated victims in recent years. Therefore, investigators have to use some methods to identify the mutilated victims. Measuring the length of a body when it is still intact is not difficult, but the challenge will arise when the body has undergone severe damage or is not intact anymore. This study aimed to determine the correlation of the length of the radius to height. This was a descriptive study. Samples were 140 students (males and females) of the Faculty of Medicine, University of Sam Ratulangi Manado. The results showed that by using the regression coefficient in males: height $=84+3.2 \times$ average radial length, the regression coefficient 3.2 means that a male's height increases $3.2 \mathrm{~cm}$ for each $1 \mathrm{~cm}$ increase of radial length. However, the regression coefficient for females: height $=56+4.1 \times$ average radial length, the regression coefficient 4.1 means that height increases $4.1 \mathrm{~cm}$ for each $1 \mathrm{~cm}$ increase of radial length. Conclusion: Height can be determined by the avereage radial length by using the regression coefficients for males 4.1 and for females 3.2.
\end{abstract}

Keywords: gender, radial length, height

\begin{abstract}
Abstrak: Terjadinya peningkatan kasus-kasus korban mutilasi pada akhir-akhir ini membuat penulis berpikir bahwa proses identifikasi sangat dibutuhkan oleh penyidik untuk mengungkap identitas korban mutilasi tersebut. mengukur panjang badan jenazah bila masih utuh bukanlah merupakan suatu pekerjaan yang sulit, namun kesulitan akan muncul bila jenazah mengalami kerusakan yang sangat hebat atau tidak lagi utuh. Penelitian ini bertujuan untuk menentukan nilai korelasi panjang radius dengan tinggi badan pada mahasiswa/i Fakultas Kedokteran Universitas Sam Ratulangi Manado. Penelitian ini bersifat deskriptif. Sampel terdiri dari 140 mahasiswa/i. Hasil penelitian memperlihatkan bahwa pada laki-laki tinggi badan $(\mathrm{TB})=84+3,2 \mathrm{x}$ panjang rata-rata radius. Nilai koefisien regresi 3,2 berarti tinggi badan pada laki-laki akan bertambah sebesar $3,2 \mathrm{~cm}$ bila panjang rata-rata tulang radius bertambah $1 \mathrm{~cm}$. Pada perempuan $\mathrm{TB}=56+4,1 \mathrm{x}$ panjang rata-rata radius. Nilai koefisien regresi 4,1 berarti tinggi badan pada perempuan akan bertambah sebesar 4,1 cm bila panjang rata-rata tulang radius bertambah $1 \mathrm{~cm}$. Simpulan: Tinggi badan dapat ditentukan dengan menggunakan panjang rata-rata radius dan koefisien regresi yaitu untuk laki-laki 4,1 dan untuk perempuan 3,2.
\end{abstract}

Kata kunci: jenis kelamin, panjang radius, tinggi badan

Secara definisi disebutkan bahwa ilmu kedokteran forensik adalah cabang spesialistik dari ilmu kedokteran yang mempelajari pemanfaatan ilmu kedokteran untuk kepentingan penegakan hukum serta keadilan. ${ }^{1}$ Seiring dengan perkembangan zaman dan perjalanan waktu, ilmu kedokteran forensik terus berkembang menjadi suatu 
ilmu yang universal karena meliputi berbagai aspek ilmu pengetahuan. Salah satu bidang penting dalam kedokteran forensik adalah identifikasi. $^{2}$

Untuk kepentingan Visum et Repertum (VeR), ketika dokter memeriksa jenazah maka identifikasi pada jenazah tetap dilakukan sekalipun jenazah tersebut dikenal. Dokter harus mencatat jenis kelamin, umur, suku bangsa, panjang dan berat badan, kebangsaan, warna kulit, perawakan, rambut, mata, gigi, bekas-bekas luka, tahi lalat, tato, pakaian, perhiasan, barang-barang yang ada pada jenazah, ada tidaknya kumis/ jenggot (pada laki-laki) dan sebagainya. ${ }^{2-4}$

Dalam bidang kedokteran forensik peranan pemeriksaan identifikasi sangatlah penting pada korban yang telah meninggal, hal ini oleh karena setelah dilakukan identifikasi terhadap jenazah untuk kepastian identitas, barulah kemudian pemeriksaan dapat dilakukan pada tingkat berikutnya pada jenazah yang sejak semula tidak dikenal atau biasa disebut dengan istilah Mr.X, tentunya identifikasi menjadi sulit bila mayat yang dikirim ke rumah sakit atau puskesmas telah mengalami pembusukan atau mengalami kerusakan berat baik akibat kebakaran, ledakan, kecelakaan pesawat, ataupun tinggal sebagian jaringan tubuh misalnya pada kasus mutilasi. Pada kondisi tersebut tidak jarang pihak kepolisian (penyidik) hanya menyerahkan kepala saja, sebagian lengan atau kaki yang terpotong-potong atau kadang kala tinggal tulang belulang saja. ${ }^{1,3}$

Terjadinya peningkatan kasus-kasus korban mutilasi pada akhir-akhir ini membuat penulis berpikir bahwa proses identifikasi sangat dibutuhkan oleh penyidik untuk mengungkap identitas korban mutilasi tersebut. Menurut data yang diperoleh penulis dari media cetak, Kabareskrim Mabes Polri; Irjen. Pol. Drs. Susno Duadji, SH menyatakan bahwa di wilayah hukum Polda Metro Jaya saja sepanjang tahun 2008 tercatat 6 (enam) kasus mutilasi, dan yang paling menggemparkan adalah kasus korban mutilasi Heri Santoso yang dimutilasi menjadi tujuh potongan dengan pelaku mutilasi adalah Very Idam Heriyansyah alias Ryan dari Jombang. ${ }^{5}$

Mengukur panjang badan jenazah bila masih utuh bukanlah merupakan suatu pekerjaan yang sulit, namun kesulitan akan muncul bila jenazah mengalami kerusakan yang sangat hebat atau tidak lagi utuh., ${ }^{2,6}$

Pada saat jenazah tidak lagi utuh, perkiraan panjang jenazah dapat dilakukan dengan mengukur bagian tertentu tubuh jenazah untuk memperkirakan tinggi badan seseorang pada saat masih hidup. Ada beberapa pengukuran bagian tubuh yang dapat dilakukan untuk memperkirakan tinggi badan secara umum adalah dengan mengukur jarak kedua ujung jari kanan dan kiri, mengukur panjang puncak kepala sampai symphisis pubis dikali dua, panjang salah satu ujung jari tengah sampai olecranon sisi yang sama dikali tiga koma tujuh, panjang femur dikali empat, ataupun panjang humerus dikali enam, yang semua perhitungan tersebut dapat memperkiran panjang jenazah (tinggi badan) seseorang. ${ }^{2}$

Pada kasus mutilasi, selain jari-jari tangan/telapak tangan, kepala juga menjadi bagian yang paling sering menjadi incaran pelaku kejahatan untuk dihilangkan, dimana hal tersebut dilakukan tentunya untuk menghilangkan identitas si korban. Beberapa cara memisahkan bagian tubuh yang sering terjadi pada kasus mutilasi adalah dengan memisahkan kepala pada daerah leher, memisahkan tangan pada daerah ketiak, siku ataupun pergelangan tangan, memisahkan kaki pada daerah paha atau lutut. ${ }^{6,7}$

Penelitian ini bertujuan untuk mencari korelasi panjang tulang radius dengan tinggi badan yang dilakukan pada mahasiswa/i Fakultas Kedokteran Unsrat Manado angkatan 2010. Hasil penelitian ini diharapkan dapat membantu dalam mengidentifikasi tinggi badan seseorang.

\section{METODE PENELITIAN}

Jenis penelitian yang dilakukan bersifat deskriptif dengan tujuan mendapatkan suatu data yang aktual tentang korelasi antara panjang tulang radius dengan tinggi badan pada mahasiswa Fakultas Kedok- 
teran Unsrat Manado angkatan 2010.

\section{Subjek Penelitian}

Populasi penelitian yang digunakan yaitu mahasiswa Fakultas Kedokteran Unsrat Manado angkatan 2010 dengan jumlah mahasiswa/i 280 orang. Kriteria inklusi yaitu; usia 17-22 tahun, tidak menunjukkan suatu kelainan muskuloskeletal, dan bersedia ikut serta dan mau membantu penelitian ini.

\section{Sampel}

Besar sampel diperoleh dengan rumus yang dikembangkan oleh Snedecor dan Cochran:

$$
\mathrm{n}=\frac{1}{d^{2}} \quad \mathrm{n}_{\mathrm{k}}=\frac{n}{1+\frac{n}{N}}
$$

$\mathrm{n}_{\mathrm{k}} \quad$ = besarnya sampel setelah koreksi

n = besarnya sampel sebelum di koreksi

$\mathrm{N}$ = besarnya populasi

$\mathrm{d}=$ derajat kecermatan yang diinginkan, lazimnya $5 \%$

$$
\begin{gathered}
\mathrm{n}=\frac{1}{5 \%^{2}} \\
\mathrm{n}=\frac{1}{0,0025} \\
\mathrm{n}=400 \\
\mathrm{n}_{\mathrm{k}}=\frac{400}{1+\frac{400}{280}} \\
\mathrm{n}_{\mathrm{k}}=\frac{400}{1+1.42} \\
\mathrm{n}_{\mathrm{k}}=166,2
\end{gathered}
$$

Dari perhitungan diatas maka di perlukan sampel sebanyak 166 orang dari 280 orang jumlah mahasiswa/i Fakultas Kedokteran Unsrat angkatan 2010.

Pengambilan sampel menggunakan teknik yang memberi peluang sama bagi setiap populasi untuk dipilih menjadi sampel dengan metode simple random sampling.

Penelitian ini dilakukan selama dua bulan, dimulai pengambilan sampel, pengolahan dan penyajian data dari bulan Desember 2011-Januari 2012.

Penelitian dilakukan di Fakultas kedokteran UNSRAT. Variabel terikat berupa panjang tulang radius dan variabel bebas yakni tinggi badan.

\section{Definisi Operasional}

1. Tinggi badan ialah jarak dari tumit sampai vertex dalam posisi berdiri tegak lurus.

2. Panjang radius ialah jarak antara ujung paling proximal pada caput radius dan titik paling distal pada processus styloideus.

\section{Alat dan bahan}

Lembar isian data berupa daftar identitas subjek peneliti, yaitu nama, jenis kelamin, umur, tempat dan tanggal lahir, tinggi badan dan panjang tulang radius.

Alat ukur tinggi badan microtoice (satuan $\mathrm{cm}$ ), yang panjangnya $200 \mathrm{~cm}$ dengan tingkat ketelitian 0,1 cm (Gambar 1).

Pita ukur yang panjangnya $150 \mathrm{~cm}$ dengan tingkat ketelitian $0,1 \mathrm{~cm}$.

Lembar persetujuan yang berisi penjelasan mengenai proses pelaksanaan penelitian dan disetujui serta ditanda tangani oleh subjek peneliti, terakhir Alat tulis menulis.

\section{Cara Penelitian}

\section{Cara pemasangan microtoice}

1. Gantungkan bandul, benang untuk membantu memasang microtoice di dinding agar tegak lurus.

2. Letakan alat ukur di lantai yang datar tidak jauh dari bandul tersebut dan menempel pada dinding. Dinding jangan ada lekukan atau tonjolan.

3. Tarik papan penggeser tegak lurus keatas, sejajar dengan benang bandul yang tergantung dan tarik sampai angka pada jendela baca menunjukkan angka 
0. Kemudian dipaku pada bagian atas microtoice.

4. Untuk menghindari terjadi perubahan posisi pita, beri perekat pada posisi sekitar $10 \mathrm{~cm}$ dari bagian atas microtoice.

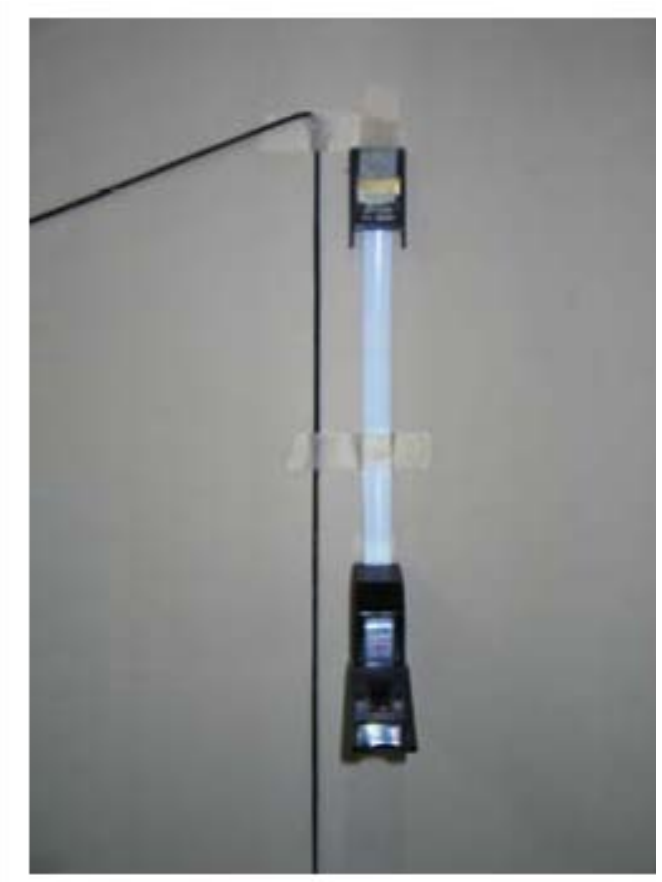

Gambar 1. Cara Pemasangan Microtoice. ${ }^{8}$

\section{Cara pengukuran tinggi badan}

1. Minta resonden untuk melepas alas kaki, topi.

2. Pastikan alat geser berada pada posisi atas.

3. Responden diminta berdiri tegak, persis di bawah alat geser.

4. Posisi kepala dan bahu bagian belakang, lengan, pantat dan tumit menempel pada dinding tempat microtoice di pasang.

5. Pandangan lurus ke depan, dan tangan dalam posisi tergantung bebas.

6. Gerakan alat geser sampai menyentuh bagian atas kepala responden. Pastikan alat geser berada tepat di tengah kepala responden. Dalam keadaan ini bagian belakang alat geser harus tetap menempel pada dinding.

7. Baca angka tinggi badan pada jendela baca ke arah angka yang lebih besar. Pembacaan dilakukan tepat di depan angka pada garis merah, sejajar dengan mata petugas.

8. Apabila pengukur lebih rendah dari yang diukur, pengukur harus berdiri di atas bangku agar hasil pembacaannya benar.

9. Pencatatan dilakukan dengan teliti sampai satu angka dibelakang koma.

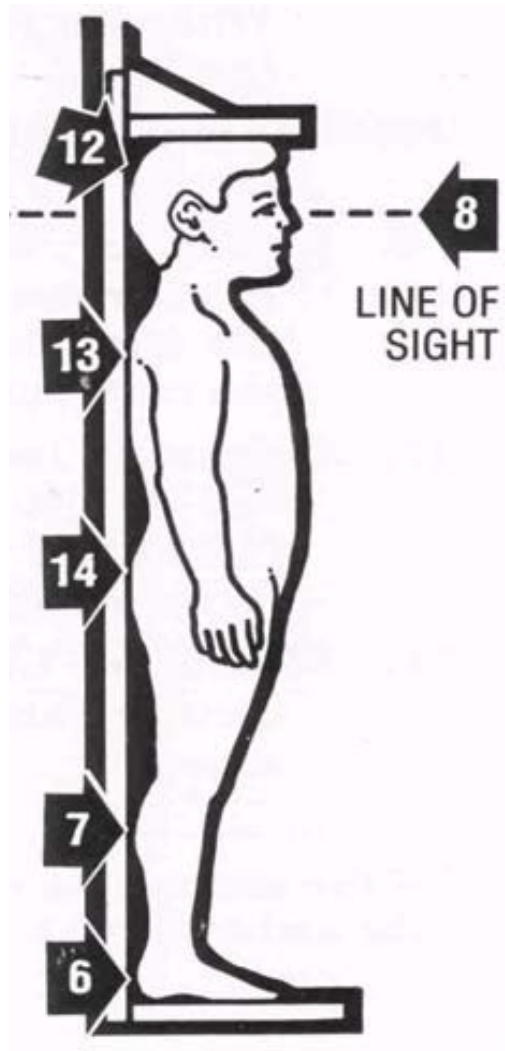

Gambar 2. Cara mengukur tinggi badan. ${ }^{8}$

\section{Pengukuran panjang radius}

1. Responden diminta berdiri dengan posisi anatomis.

2. Lalu diukur panjang radius dari caput radius sampai proesus stiloideus.

3. Kemudian petugas pengukur membaca angka yang tertera dan mencatatnya.

4. Panjang radius dicatat dalam satuan centimeter sampai satu angka dibelakang koma.

\section{Analisis data}

Berdasarkan data variabel umur, tinggi badan dan panjang radius yang sudah didapat, dihitung rata-rata dan simpangan 
baku variabel umur, tinggi badan dan panjang radius. Kemudian ditentukan korelasi dan regresi antara panjang tulang radius dengan tinggi badan dengan menggunakan program komputerisasi SPSS versi 19 dengan persamaan $\mathrm{Y}=\mathrm{a}+\mathrm{bX}$.

\section{HASIL PENELITIAN}

\section{Karakteristik subjek penelitian}

Penelitian yang dilakukan di Bagian Anatomi-Histologi Fakultas Kedokteran Universitas Sam Ratulangi yang dilakukan pada tanggal 28 dan 29-11-2011 pada 140 orang sampel terdiri dari 70 orang laki-laki dan 70 orang perempuan.

Pada Tabel 1, subjek penelitian lakilaki berusia antara 17-22 tahun dengan usia rata-rata 18,8 tahun dan simpangan baku 0,8 tahun. Subjek penelitian perempuan berusia antara 17-21 tahun dan usia ratarata 18,7 tahun dengan standar deviasi 0,7 tahun. Usia untuk keseluruhan berkisar antara 17-22 tahun dengan usia rata-rata 18,8 tahun dan simpangan baku 0,8 tahun.

Tabel 1. Usia subjek penelitian

\begin{tabular}{ccccc}
\hline $\begin{array}{c}\text { Subjek } \\
\text { penelitian }\end{array}$ & $\begin{array}{c}\text { Jumlah } \\
\text { subjek } \\
\text { (orang) }\end{array}$ & $\begin{array}{c}\text { Usia } \\
\text { (tahun) }\end{array}$ & $\begin{array}{c}\text { Rata- } \\
\text { rata } \\
\text { (tahun) }\end{array}$ & $\begin{array}{c}\text { Simpang } \\
\text { an baku } \\
\text { (tahun) }\end{array}$ \\
\hline $\begin{array}{c}\text { Laki-laki } \\
\text { Perem- } \\
\text { puan }\end{array}$ & 70 & $17-22$ & 18,8 & 0,8 \\
Jumlah & 140 & $17-21$ & 18,7 & 0,7 \\
\hline
\end{tabular}

Tabel 2 memperlihatkan tinggi badan laki-laki antara 151-180 cm dengan ratarata 168,5 cm dan simpangan baku 5,1 cm. Tinggi badan perempuan antara 143-168 cm dengan rata-rata $156 \mathrm{~cm}$ dan simpangan baku 6,1 cm. Tinggi badan seluruhnya berkisar antara 143-180 cm dengan ratarata $162,2 \mathrm{~cm}$ dan simpangan baku $8,4 \mathrm{~cm}$.

Pada Tabel 3, panjang radius kanan laki-laki antara 23,5-29 cm dengan rata-rata 26,6 cm dan simpangan baku 1,1 cm. Panjang radius kanan perempuan antara 21-27 cm dengan rata-rata $24,7 \mathrm{~cm}$ dan simpangan baku 1,1 cm. Panjang radius kanan seluruhnya antara 21-29 cm dengan ratarata 25,6 cm dan simpangan baku 1,5 cm.

Tabel 2. Tinggi badan subjek penelitian

\begin{tabular}{ccccc}
\hline $\begin{array}{c}\text { Subjek } \\
\text { penelitian }\end{array}$ & $\begin{array}{c}\text { Jumlah } \\
\text { subjek } \\
\text { (orang) }\end{array}$ & $\begin{array}{c}\text { Tinggi } \\
\text { badan } \\
\text { (cm) }\end{array}$ & $\begin{array}{c}\text { Rata- } \\
\text { rata } \\
\text { (cm) }\end{array}$ & $\begin{array}{c}\text { Simpanga } \\
\text { an } \\
\text { baku (cm) }\end{array}$ \\
\hline $\begin{array}{c}\text { Laki-laki } \\
\text { Perem- } \\
\text { puan }\end{array}$ & 70 & $151-180$ & 168,5 & 5,1 \\
Jumlah & 140 & $143-168$ & 156 & 6,1 \\
\hline
\end{tabular}

Tabel 3. Panjang radius kanan subjek penelitian

\begin{tabular}{ccccc}
\hline $\begin{array}{c}\text { Subjek } \\
\text { penelitian }\end{array}$ & $\begin{array}{c}\text { Jumlah } \\
\text { subjek } \\
\text { (orang) }\end{array}$ & $\begin{array}{c}\text { Panjang } \\
\text { radius } \\
\text { kanan } \\
\text { (cm) }\end{array}$ & $\begin{array}{c}\text { Rata- } \\
\text { rata } \\
\text { (cm) }\end{array}$ & $\begin{array}{c}\text { Sim- } \\
\text { pangan } \\
\text { baku } \\
\text { (cm) }\end{array}$ \\
\hline Laki-laki & 70 & $23,5-29$ & 26,6 & 1,1 \\
Perempuan & 70 & $21-27$ & 24,7 & 1,1 \\
Jumlah & 140 & $21-29$ & 25,6 & 1,5 \\
\hline
\end{tabular}

Dari Tabel 4, panjang radius kiri lakilaki antara 23,5-29 cm dengan rata-rata 26,6 cm dan simpangan baku $1,1 \mathrm{~cm}$. Panjang radius kiri perempuan antara 20,5$27 \mathrm{~cm}$ dengan rata-rata $24,6 \mathrm{~cm}$ dan simpangan baku 1,2 cm. Panjang radius kiri seluruhnya antara 20,5-29 cm dengan ratarata 25,6 cm dan simpangan baku $1,5 \mathrm{~cm}$.

Tabel 4. Panjang radius kiri subjek penelitian

\begin{tabular}{ccccc}
\hline $\begin{array}{c}\text { Subjek } \\
\text { penelitian }\end{array}$ & $\begin{array}{c}\text { Jumlah } \\
\text { subjek } \\
\text { (orang) }\end{array}$ & $\begin{array}{c}\text { Panjang } \\
\text { radius kiri } \\
\text { (cm) }\end{array}$ & $\begin{array}{c}\text { Rata- } \\
\text { rata } \\
\text { (cm) }\end{array}$ & $\begin{array}{c}\text { Sim- } \\
\text { pangan } \\
\text { baku } \\
\text { (cm) }\end{array}$ \\
\hline $\begin{array}{c}\text { Laki-laki } \\
\text { Perem- } \\
\text { puan }\end{array}$ & 70 & $23,5-29$ & 26,6 & 1,1 \\
Jumlah & 140 & $20,5-27$ & 24,6 & 1,2 \\
\hline
\end{tabular}

Tabel 5 memperlihatkan panjang radius laki-laki antara $24-29 \mathrm{~cm}$ dengan rata-rata 26,6 cm dan simpangan baku 1,1 $\mathrm{cm}$. Panjang radius perempuan antara 21$27 \mathrm{~cm}$ dengan rata-rata 24,6 $\mathrm{cm}$ dan simpangan baku 1,1 cm. Panjang radius seluruhnya antara 21-29 cm dengan ratarata 25,6 cm dan sim-pangan baku 1,4 cm. 
Tabel 5. Panjang radius semua penelitian.

\begin{tabular}{ccccc}
\hline $\begin{array}{c}\text { Subjek } \\
\text { penelitian }\end{array}$ & $\begin{array}{c}\text { Jumlah } \\
\text { subjek } \\
\text { (orang) }\end{array}$ & $\begin{array}{c}\text { Panjang } \\
\text { radius } \\
\text { (cm) }\end{array}$ & $\begin{array}{c}\text { Rata } \\
\text {-rata } \\
\text { (cm) }\end{array}$ & $\begin{array}{c}\text { Simpangan } \\
\text { baku (cm) }\end{array}$ \\
\hline Laki-laki & 140 & $24-29$ & 26,6 & 1,1 \\
Perempuan & 140 & $21-27$ & 24,6 & 1,1 \\
Jumlah & 140 & $21-29$ & 25,6 & 1,4 \\
\hline
\end{tabular}

Korelasi panjang radius dengan tinggi badan

\section{Analisis regresi antara panjang radius dengan tinggi badan pada seluruh subjek penelitian}

Nilai koefisien determinasi dapat dilihat dari nilai $\mathrm{R}^{2}$ yaitu 0,74 artinya, persamaan garis regresi yang diperoleh dapat menerangkan $74 \%$ variasi panjang radius. Nilai $\mathrm{r}$ yaitu 0,86 menunjukkan hubungan yang sangat erat, selanjutnya nilai $P$ sebesar 0,0001 berarti pada $\alpha 1 \%$ disimpulkan regresi sederhana cocok dengan data yang ada. Persamaan garis regresi bernilai 4,8 (Tabel 6).

Tabel 6. Analisis regresi pada seluruh subjek penelitian.

\begin{tabular}{ccccc}
\hline Variabel & $\begin{array}{c}\text { Nilai } \\
\boldsymbol{P}\end{array}$ & $\mathbf{R}$ & $\mathbf{R}^{2}$ & $\begin{array}{c}\text { Persama- } \\
\text { an garis } \\
\text { Regresi }\end{array}$ \\
\hline $\begin{array}{c}\text { Panjang } \\
\text { Radius } \\
\text { Nilai }\end{array}$ & 0,0001 & 0,86 & 0,74 & 4,8 \\
Konstanta & 38,4 & & & \\
& & & & \\
\hline
\end{tabular}

(a)

Persamaan regresi: Tinggi badan $=38,4+4,8 \times$ Panjang rata-rata radius.

Dengan persamaan diatas, maka tinggi badan bisa diketahui dari panjang rata-rata radius. Hal ini berarti terdapat hubungan linier antara panjang tulang radius dengan tinggi badan. Dari nilai koefisien regresi 4,8 berarti tinggi badan akan bertambah sebesar $4,8 \mathrm{~cm}$ bila panjang rata-rata tulang radius bertambah $1 \mathrm{~cm}$.
Analisis regresi antara panjang radius dengan tinggi badan pada laki-laki

Nilai koefisien determinasi dapat dilihat dari nilai $\mathrm{R}^{2}$ yaitu 0,5 artinya, persamaan garis regresi yang diperoleh dapat menerangkan $50 \%$ variasi panjang radius pada laki-laki. Nilai $r$ yaitu 0,7 menunjukkan kedua variabel berhubungan kuat, selanjutnya nilai $P$ sebesar 0,0001 berarti pada $\alpha 1 \%$ disimpulkan regresi sederhana cocok dengan data yang ada. Persamaan garis bernilai 3,2 (Tabel 7).

Tabel 7. Analisis regresi pada seluruh laki-laki.

\begin{tabular}{ccccc}
\hline Variabel & $\begin{array}{c}\text { Nilai } \\
\boldsymbol{P}\end{array}$ & $\mathbf{R}$ & $\mathbf{R}^{2}$ & $\begin{array}{c}\text { Persamaan } \\
\text { garis } \\
\text { regresi }\end{array}$ \\
\hline $\begin{array}{c}\text { Panjang } \\
\text { radius } \\
\text { Nilai }\end{array}$ & 0,0001 & 0,7 & 0,5 & 3,2 \\
Konstanta & 84 & & & \\
\hline (a) & & & & \\
\hline
\end{tabular}

(a)

Persamaan regresi: Tinggi badan laki-laki= $84+3,2 \times$ Panjang rata-rata radius.

Dengan persamaan diatas, maka tinggi badan seorang laki-laki bisa diketahui jika diketahui panjang rata-rata radius pada laki-laki. Hal ini berarti terdapat hubungan linier antara panjang tulang radius dengan tinggi badan pada laki-laki. Dari nilai koefisien regresi 3,2 berarti tinggi badan pada laki-laki akan bertambah sebesar 3,2 cm bila panjang rata-rata tulang radius bertambah $1 \mathrm{~cm}$.

\section{Analisis regresi antara panjang radius dengan tinggi badan pada perempuan}

Nilai koefisien determinasi dapat dilihat dari nilai $\mathrm{R}^{2}$ yaitu 0,59 artinya, persamaan garis regresi yang diperoleh dapat menerangkan 59\% variasi panjang radius. Nilai $\mathrm{r}$ yaitu 0,7 menunjukkan variabel berhubungan kuat, selanjutnya nilai $P$ sebesar 0,0001 berarti pada $\alpha 1 \%$ disimpulkan regresi sederhana cocok dengan data yang ada. Persamaan garis bernilai 4,1 (Tabel 8). 
Tabel 8. Analisis regresi pada seluruh perempuan.

\begin{tabular}{ccccc}
\hline Variabel & $\begin{array}{c}\text { Nilai } \\
\boldsymbol{P}\end{array}$ & $\mathbf{R}$ & $\mathbf{R}^{2}$ & $\begin{array}{c}\text { Persamaan } \\
\text { garis } \\
\text { regresi }\end{array}$ \\
\hline $\begin{array}{c}\text { Panjang } \\
\text { radius } \\
\text { Nilai }\end{array}$ & 0,0001 & 0,7 & 0,59 & 4,1 \\
$\begin{array}{c}\text { Konstanta } \\
\text { (a) }\end{array}$ & & & & \\
\hline
\end{tabular}

Persamaan regresi: Tinggi badan perempuan= $56+4,1 \times$ Panjang rata-rata radius.

Dengan persamaan diatas, maka tinggi badan seorang perempuan bisa diketahui jika diketahui panjang rata-rata radius pada perempuan. Hal ini berarti terdapat hubungan linier antara panjang tulang radius dengan tinggi badan pada perempuan. Dari nilai koefisien regresi 4,1 berarti tinggi badan pada perempuan akan bertambah sebesar 4,1 cm bila panjang rata-rata tulang radius bertambah $1 \mathrm{~cm}$.

\section{BAHASAN}

Panjang badan merupakan salah satu data untuk identifikasi yang perlu diukur pada mayat. Pada keadaan mayat berupa kerangka atau potongan tubuh, panjang badan dapat diperoleh ber-dasarkan rumus regresi, faktor multiplikasi atau ratio bangun tubuh terhadap tinggi badan.

Rumus yang menghubungkan tinggi badan dengan komponen tubuh, seperti tulang panjang telah banyak dilaporkan. Saat ini telah disadari bahwa cara yang terbaik ialah bila rumus tinggi badan diperoleh dari data hasil penelitian pada populasi yang bersangkutan.

Pada penelitian ini digunakan subjek penelitian mahasiswa FK Unsrat Manado yang berusia antara 17-22 tahun dengan pertimbangan tinggi badan sudah stabil (di atas 17 tahun) tetapi belum mengalami penyusutan akibat usia. Telah dilakukan pengukuran terhadap 140 mahasiswa/i yang terdiri dari 70 orang laki-laki dan 70 orang perempuan. Data usia subjek penelitian ini (Tabel 1) yaitu untuk laki-laki yang berusia antara 17-22 tahun mempunyai usia 18,8 \pm
0,8 tahun; dan untuk perempuan yang berusia antara 17-21 tahun mempunyai usia $18,7 \pm 0,7$ tahun. Untuk keseluruhan subjek penelitian yang berusia antara 17-22 tahun mempunyai usia18,8 $\pm 0,8$ tahun.

Pada Tabel 2, tinggi badan untuk keseluruhan subjek penelitian antara 143$180 \mathrm{~cm}$ mempunyai tinggi badan 162,2 \pm 8,4 cm. Jika dibedakan berdasarkan jenis kelamin maka ditemukan tinggi badan lakilaki lebih panjang daripada tinggi badan perempuan, yaitu tinggi badan laki-laki antara 151-180 cm mempunyai tinggi badan 168,5 $\pm 5,1 \mathrm{~cm}$ dan tinggi badan perempuan antara 143-168 cm mempunyai tinggi badan $156 \pm 6,1 \mathrm{~cm}$.

Pada Tabel 3 dan 4 didapatkan hasil penelitian yang membedakan antara radius kanan dan kiri dimana didapatkan panjang radius kanan dan kiri pada laki-laki lebih panjang daripada panjang radius kanan dan kiri pada perempuan. Panjang radius kanan pada Tabel 3 menunjukkan bahwa pada keseluruhan subjek penelitian besarnya antara 21-29 cm, atau 25,6 $\pm 1,5 \mathrm{~cm}$. Untuk laki-laki besarnya antara 23,5-29 $\mathrm{cm}$ atau 26,6 $\pm 1,1 \mathrm{~cm}$ dan pada perempuan besarnya antara $21-27 \mathrm{~cm}$, atau 24,7 $\pm 1,1$ $\mathrm{cm}$. Panjang radius kiri pada Tabel 4 menunjukkan bahwa pada keseluruhan subjek penelitian besarnya antara 20,5-29 $\mathrm{cm}$, atau 25,6 $\pm 1,5 \mathrm{~cm}$. Untuk laki-laki besarnya antara 23,5-29 cm, atau 26,6 $\pm 1,1$ cm dan pada perempuan besarnya antara 20,5-27 cm, atau 24,6 $\pm 1,2 \mathrm{~cm}$.

Keseluruhan panjang radius kanan dan kiri dapat dilihat pada Tabel 5, yaitu panjang radius keseluruhan besarnya antara 21-29 cm, atau 25,6 $\pm 1,4 \mathrm{~cm}$. Untuk lakilaki panjang radius keseluruhan antara 24$29 \mathrm{~cm}$, atau 26,6 $\pm 1,1 \mathrm{~cm}$, dan pada perempuan panjang radius keseluruhan antara 21-27 cm, atau 24,6 $\pm 1,1 \mathrm{~cm}$.

Dari hasil penelitian pada Tabel 2 (tinggi badan) dihubungkan dengan Tabel 3 , 4, dan 5 (panjang radius) didapatkan perbandingan yang berbanding lurus antara tinggi badan dengan panjang radius. Hal ini berarti semakin besar panjang radius, maka semakin besar pula tinggi badan.

Pada Tabel 3 dan 4 (panjang radius ka- 
nan dan kiri) ditemukan perbedaan yaitu nilai rata-rata untuk radius kanan sedikit lebih panjang dibandingkan dengan radius kiri pada perempuan. Hal ini mungkin disebabkan oleh karena sebagian besar subjek penelitian lebih banyak beraktivitas dengan menggunakan tangan kanan.

Setelah semua data terkumpul dilakukan analisis regresi antara panjang radius baik kanan maupun kiri dengan tinggi badan pada laki-laki maupun pada perempuan dan juga pada keseluruhan subjek penelitian. Pada subjek penelitian secara keseluruhan untuk radius kanan dan kiri didapatkan nilai koefisien korelasi $(r)=4,8$. Untuk laki-laki koefisien korelasinya $(\mathrm{r})=$ 3,2 sedangkan untuk perempuan koefisien korelasinya $(r)=4,1$. Dari hasil analisis ini didapatkan nilai korelasi yang kuat antara panjang radius dengan tinggi badan.

Melalui analisis regresi didapatkan rumus persamaan untuk memperkirakan tinggi badan dengan panjang radius. Pada keseluruhan subjek penelitian, didapatkan persamaan Tinggi Badan $=38,4+4,8 \times$ panjang rata-rata radius. Untuk subjek penelitian laki-laki persamaan Tinggi badan $=84+3,2 \times$ panjang rata-rata radius, sedangkan untuk subjek penelitian perempuan persamaan Tinggi Badan $=56+4,1 \times$ panjang rata-rata radius.

\section{SIMPULAN}

Dari hasil penelitian ini disimpulkan bahwa perkiraan tinggi badan seseorang dapat ditentukan berdasarkan panjang tulang radius kanan maupun kiri pada kedua jenis kelamin laki-laki dan perempuan dengan menggunakan rumus regresi. Pada laki-laki digunakan rumus TB $=84+3,2 \times$ Panjang rata-rata radius (laki-laki). Nilai koefisien regresi 3,2 berarti tinggi badan pada laki-laki akan bertambah sebesar 3,2 cm bila panjang rata-rata tulang radius bertambah $1 \mathrm{~cm}$. Pada perempuan digunakan rumus $\mathrm{TB}=56+4,1 \times$ Panjang ratarata radius. Nilai koefisien regresi 4,1 berarti tinggi badan pada perempuan akan bertambah sebesar 4,1 cm bila panjang rata-rata tulang radius bertambah $1 \mathrm{~cm}$.

\section{DAFTAR PUSTAKA}

1. Budyanto A, Widiatmaka W, Atmaja DS, dkk. Identifikasi forensik. In: Ilmu Kedokteran Forensik. Jakarta: Bagian Kedokteran FK-UI, 1999; p.197-202.

2. Amir A. Identifikasi. In: Rangkaian Ilmu Kedokteran Forensik (Edisi Kedua). Medan: Bagian Ilmu Kedokteran Forensik FK-USU, 2005; p. 178-203.

3. Hamdani N. Identifikasi mayat. In: Ilmu Kedokteran Kehakiman (Edisi Kedua). Jakarta: PT Gramedia Pustaka Utama, 1992; p. 83-8.

4. Wiliam DJ, Ansford AJ, Friday DS, et al. Identification. In: Colour Guide Forensic Pathology. Churchill Livingstone, 2002; 13-7.

5. Tandjung Y. Kejahatan MUTILASI (Criminal Version) [homepage on the Internet]. c2008. [updated 2008 Jun 04; cited 2013 Jun 15]. Available from: http://yuhendrablog.wordpress.com/200 8/06/04/kejahatan-mutilasi-criminalversion/

6. Nandy A. Identification of an individual. In: Principles of Forensic Medicine. Calcutta: New Central Book Agency (P) Ltd., 1996; p. 47-109.

7. Franklin CA. Postmortem examination (autopsy). In: Modi's Textbook of Medical Jurisprudence and Toxicology (Twenty- First Edition). Bombay: Tripathi Private Limited, 1988; p. 6995.

8. Riset Kesehatan Dasar. Pedoman Pengukuran dan Pemeriksaan [homepage on the Internet]. Nodate [cited 2013 Jan 20]. Available from:http://www.google. co.id/url?sa=t\&rct $=\mathrm{j} \& \mathrm{q}=$ microtoice \&so urce $=$ web \&cd $=2 \&$ ved $=0$ CCUQFjAB \& url=http\%3A\%2F\%2Fwww.litbang.dep kes.go.id\%2Friskesdas\%2Fdownload\% 2Fpedoman_pengukuran.pdf\&ei=Us2 TorkFsmzrAesxriTBQ\&usg=AFQjCN GFoVyRmmXecDI8GQbmlm1VOJIU_ Q\&cad=rja

9. Putz R, Pabst R. Sobotta Atlas Anatomi Manusia Jilid 2 (Edisi 22). Jakarta: EGC, 2007. 